\title{
Study of Temperature and Use of Catalysts in the Pyrolysis of LDPE Plastic Waste on the Quantity of Oil Fuel Products Produced
}

\author{
Novarini $^{1}$ Rusdianasari $^{2, *}$ Yohandri Bow ${ }^{3}$ Sigit Kurniawan ${ }^{4}$ \\ ${ }^{1}$ Mechanical Engineering Department, Politeknik Jambi, Jambi, Indonesia \\ ${ }^{2}$ Chemical Engineering Department, Politeknik Negeri Sriwijaya, Palembang, Indonesia \\ ${ }^{3}$ Energy Engineering Department, Politeknik Negeri Sriwijaya, Palembang, Indonesia \\ ${ }^{4}$ Electronic Engineering Department, Politeknik Jambi, Jambi, Indonesia \\ *Corresponding Author: rusdianasari@polsri.ac.id
}

\begin{abstract}
Low Density Poly Ethylene (LPDE) plastic waste has no sale value, buried in a landfill. The plastic itself cannot be broken down by microorganisms in the soil, so that people destroy it through incineration. Incineration plastics produce NOx, COx, SOx, particulates, dioxins, furans, and smoke, which can increase air pollution with acid rain and global warming. The purpose of this research is to solve this plastic waste so that it can be reprocessed into more valuable fuel through the pyrolysis process. The pyrolysis equipment used is a reactor unit made of stainless steel and equipped with an insulator made from rock wall. The primary tar reservoir is between the reactor outlet channel and the condenser inlet. The condenser unit is made of a steel shell and a spiral-shaped copper tube where the condensed product is a secondary tar product. The pyrolysis process produces 3 products, namely solid residue (char), liquid product (tar), and gas products. The number of products analyzed in this study only char and tar in the pyrolysis of LDPE plastic waste was analyzed based on temperature variations, namely $200^{\circ} \mathrm{C}, 250^{\circ} \mathrm{C}$, and $300^{\circ} \mathrm{C}$. The process in the reactor using natural zeolite catalysts. The results obtained are the highest quantity of char $10.80 \%$ and the primary $\operatorname{tar} 81.19 \%$ by processing in a reactor with a temperature of $200^{\circ} \mathrm{C}$ without the use of a catalyst, the secondary tar product $91.01 \%$ by processing in a reactor temperature of $300^{\circ} \mathrm{C}$ using a catalyst. The highest yield of fuel oil was $94.80 \%$, and the lowest remaining solids residue was $5.2 \%$ in the reactor process using a catalyst with a temperature of $300^{\circ} \mathrm{C}$ for 6 hours.
\end{abstract}

Keywords: catalyst, LDPE plastic waste, pyrolysis, temperature

\section{INTRODUCTION}

Destruction of plastic waste through uncontrolled incineration with a temperature of more than $850^{\circ} \mathrm{C}$ produces Polychlorinated benzoyl-dioxine, a type of carcinogenic chemical that causes cancer and pollutants from exhaust emissions of NOx, COx, SOx, particulates, dioxins, furans, and plastic vapors that increase air pollution as well as add to global warming. A more precise processing method is needed for this solution. Pyrolysis is 1 of 4 plastic recycling technologies (mechanical recycling, incineration, chemical recycling, and pyrolysis), which are more effective in recycling plastic waste so that it can be applied in treating plastic waste to produce types of fuel oil [1][2][3][4][5].
The pyrolysis process produces 3 products, namely solid residue (char), liquid product (tar), and condensed gas or syngas. By varying the temperature in the pyrolysis process, it was found that the higher the temperature, the mass of char would decrease in proportion to the increasing mass and tar volume [6][7][8][9].

The research was conducted on the pyrolysis of plastic waste of 500 grams by varying the temperature in the pyrolysis reactor, namely $250^{\circ} \mathrm{C}, 300^{\circ} \mathrm{C}$, and $350^{\circ} \mathrm{C}$, to determine the effect on the volume of fuel oil and its characteristics. The results obtained are that with increasing temperature, the volume of fuel oil increases $[10][11][12]$.

The conversion process of plastic waste using zeolite catalysts can increase the conversion of the resulting 
product and increase the production of gas compared to liquid products. The increase in gas products reached $36.83 \%$ in the process using a batch reactor because this zeolite catalyst plays a role in helping the degradation process, thus accelerating the reaction rate [13][14][15].

Comparing thermal pyrolysis and catalytic pyrolysis using a zeolite ZSM-5 catalyst in a batch reactor with a temperature of $450{ }^{\circ} \mathrm{C}$ to the resulting product yield shows that the gas fraction is higher in catalytic pyrolysis. However, the liquid and solid fraction are higher using thermal pyrolysis. In the catalytic pyrolysis, Aluminum Silicate $25 \%$ by volume is used as a catalyst to obtain pyrolysis products, namely Pyrolysis Oil (60-70\%), gas (15-20\%), and Carbon Black (20$30 \%)$. The use of a catalyst plays a vital role in the fuel produced, increasing the amount of fuel produced [16][17][18].

\section{MATERIAL AND METHODS}

The materials used in this study were LPDE type plastic waste and 1\% natural zeolite catalyst [19] [20]. The equipment used in this study was 1 unit of LPGfueled pyrolysis equipment consisting of a reactor, tar storage, and condenser. The reactor is equipped with temperature control made of stainless steel with a thickness of $3 \mathrm{~mm}$ with a capacity of $2.5 \mathrm{~kg}$ and a height of $450 \mathrm{~mm}$, and a diameter of $320 \mathrm{~mm}$ and coated with glass wool to withstand heat transfer to the environment. The primary steel tar reservoirs were $200 \mathrm{~mm}$ high and $80 \mathrm{~mm}$ in diameter. The shell side of the condenser is made of steel with $600 \mathrm{~mm}$ height and $350 \mathrm{~mm}$ diameter. The tube is made of copper pipe with a diameter of 0.5 in and 5,000 mm length formed in a spiral wound. The product exits the condenser as a secondary tar.

LDPE plastic waste is weighed as much as $2.5 \mathrm{~kg}$ and entered from the top of the reactor. The catalyst is added together with the LDPE in the catalytic pyrolysis. The next step is to operate the gas regulator and input the desired temperature, namely a variation of $200^{\circ} \mathrm{C}$, $250^{\circ} \mathrm{C}$, and $300^{\circ} \mathrm{C}$. The next step is to operate the condenser cooling water pump. The operation of the equipment was carried out for 6 hours. After 6 hours, the volume of tar in the primary reservoir and the secondary reservoir was measured. The solid char residue that was remaining in the reactor was weighed as well. The pyrolysis apparatus is shown in Figure 1.

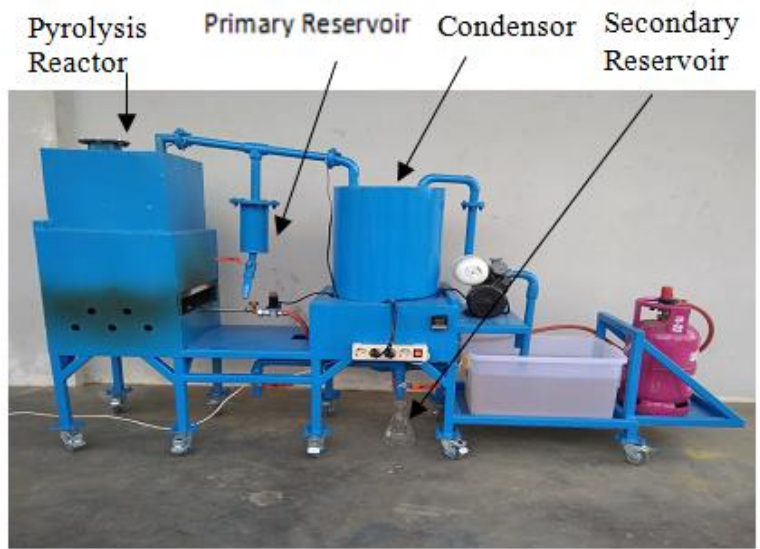

Figures 1 LDPE plastic waste pyrolysis equipment

\section{RESULT AND DISCUSSION}

Figure 2 shows the effect of temperature and the catalyst on the yield of pyrolysis products. This picture shows the yield of the pyrolysis product, namely the residue in the reactor or char, the primary liquid or tar product, and the secondary tar from the gas condensation process in the condenser. Each temperature variation is available, the resulting pyrolysis product yield data.

\subsection{Effect of Temperature on Yield Char and Tar}

It can be seen in Figure 2 that the secondary tar yield is increasing as the temperature in the reactor increased. However, the primary tar yield is affected by the temperature increase in catalytic or non-catalytic pyrolysis. In general, the increase of reaction temperature in the pyrolysis process of plastic and organic materials can increase the conversion of tar or fuel oil produced. It is due to the increasing number of tar compounds released from the decomposition of the feed with increasing temperature [2] [5][6][21].

Increasing the temperature in the reactor causes more gas to be formed, so the gas flows directly into the condenser inlet. It causes the increase of volume and yield of secondary tar results with increasing temperature. However, the volume of tar in the primary reservoir is more, and the higher yield occurs in the pyrolysis process with a lower temperature. The lower reaction temperature results in less pressure result in more gas formed from the reactor outlet trapped in the secondary tar storage channel.

The yield of char products left in the reactor decreased along with the increase in heating temperature in the reactor for both the pyrolysis process. This is due to the occurrence of plastic decomposition, which is increasingly decomposed with increasing temperature.

The reduction of char residue at temperatures of $300^{\circ} \mathrm{C}$ without a catalyst is categorized relatively high 
compared to research related to HDPE pyrolysis in thermal pyrolysis, which gets a residue char or solid fraction yield of $3 \%$ with a relatively high temperature of $450^{\circ} \mathrm{C}$ with the use of the same catalyst, natural zeolite [16].

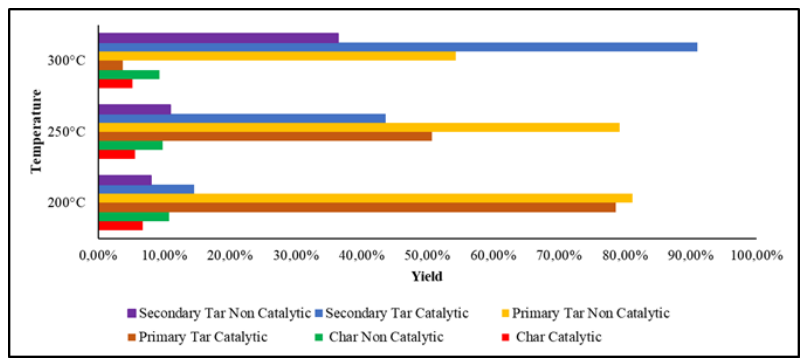

Figures 2 Effect of temperature and the use of catalysts on the yield of pyrolysis products

\subsection{The Effect of Catalyst Use on the Yield of Primary Tar and Secondary Tar}

Figure 2 shows that the use of a catalyst increases the yield of the secondary tar product but the best for the primary tar. The use of a catalyst that helps the process of cracking the LDPE plastic waste increases the volatile matter and speeds up the reaction so that the cracking of the plastic waste makes the reaction faster so that more gas leaves the reactor outlet [22]. The more gas mass due to the use of a catalyst makes the pressure also increase. The high pressure due to mass and accompanied by an increase in temperature makes the gas leaving the reactor not trapped in the primary tar reservoir but flows directly into the condenser inlet so that the volume and yield of the secondary tar condensation results in the higher the condenser.

The use of a catalyst followed by an increase in temperature is beneficial in increasing the secondary tar yield conversion value. It can be seen in Figure 2 that at a temperature of $300^{\circ} \mathrm{C}$ the secondary tar highest yield reaches $91.01 \%$ where this value has a significant increase from conditions at temperatures of $250^{\circ} \mathrm{C}$, which is equal to $66.65 \%$ and so did the increase in yield from a temperature of $200^{\circ} \mathrm{C}$ to a temperature of $250^{\circ} \mathrm{C}$ of $51.99 \%$. The yield value obtained in the secondary tar at the highest temperature of $300{ }^{\circ} \mathrm{C}$ tends to be higher than previous studies, namely the treatment of polypropylene waste by pyrolysis process at a temperature of $400^{\circ} \mathrm{C}$ using a $1 \%$ zeolite catalyst with a product yield value of $74.76 \%$ [21].

\subsection{Effect of Temperature and Use of Catalysts on the Yield of Fuel Oil}

Tar is a product of the pyrolysis process in the form of liquid condensation. Tar is produced from the vapor, which is condensed to change from gas to liquid. Tar contains water and also contains char, which is carried along during the pyrolysis process [6].

In this discussion, the tar yield at the primary reservoir and the secondary reservoir is calculated as the total tar value. From Figure 3, it can be seen that the tar yield increases with the increase of reaction temperature in the reactor, and so does the use of a catalyst. The results obtained are in accordance with the previous study, that discusses the study of the effect of temperature and the use of catalysts in the pyrolysis process [2][5][6][20][23].

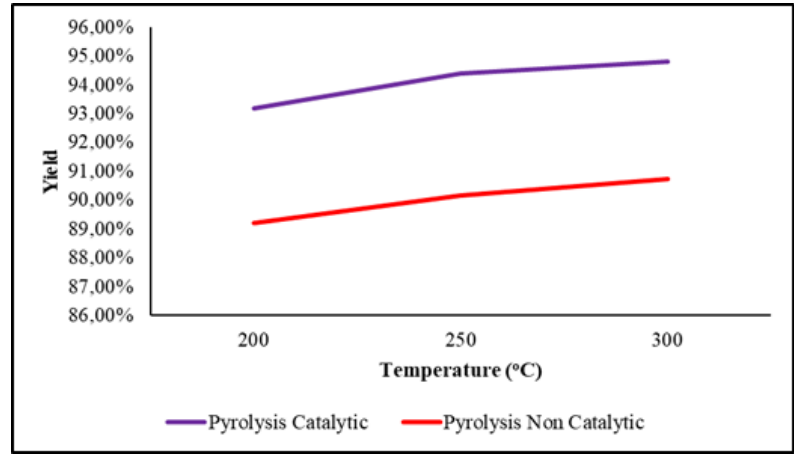

Figures 3 Effect of temperature and use of catalysts on material yield fuel oil (primary tar and secondary tar)

\section{CONCLUSIONS}

The increase in temperature and the use of catalysts can increase the yield of fuel oil and reduce the residue of solids or char left in the reactor. Pyrolysis of LDPE plastic waste uses pyrolysis equipment designed using two tar reservoirs, a stainless steel reactor, and a condenser with a copper tube in the shape of a spiral and using a natural zeolite catalyst of $1 \%$ at a temperature of $300 \mathrm{~b}^{\circ} \mathrm{C}$ to convert $2.5 \mathrm{~kg}$ of LDPE plastic waste into a tar or fuel oil by $94.80 \%$ and reducing the residual solids in the reactor by $5.2 \%$ in 6 hours.

\section{AUTHORS' CONTRIBUTIONS}

Novarini: Designed and performed experiments, analysed data and co-wrote the paper. Rusdianasari: Supervised and drafted or provided critical revision of the article research. Yohandri Bow: Provided final approval of the version to publish. Sigit Kurniawan: Performed experiments.

\section{ACKNOWLEDGMENTS}

The Ministry of Education and Culture: For the opportunity and funding facilities in this research. Chemical Engineering Department of Politeknik Negeri Sriwijaya: Providing guidance as TPM and facilitating 
product analysis. Pertamina Refinery Unit III Plaju South Sumatera: Facilitated product analysis. Politeknik Jambi: Facilitated the manufacture of tools and research data collection.

\section{REFERENCES}

[1] A. Joshi and R. Punia, "Conversion of plastic wastes into liquid fuels-a review Micro Gasifier Designing View project Plastic Waste Management View project," vol. III, p. 5 of 12, 2014, [Online]. Available: https://www.researchgate.net/publication/2810643 26.

[2] H. Porawati, "Jurnal Inovator Analisa Temperatur dan Waktu Terhadap Hasil Bahan Bakar Minyak," vol. 1, no. 2, pp. 18-21, 2018.

[3] Tahdid, Syarif, A., Trisnaliani, L., \& Effendy, S. (2020). Study of Plastic Waste Power Plants Capacity Unit 1 KWh Using Plastic Bags Based on Effectiveness Produced in Optimum Load. Journal of Physics: Conference Series, 1500(1). https://doi.org/10.1088/1742-6596/1500/1/012074

[4] Y Bow, "Pengolahan sampah low density polyethylene (LDPE) dan polypropylene (pp) menjadi bahan bakar cair alternatif menggunakan prototipe pirolisis thermal cracking," Jurnal Kinetika 9(3), 2020.

[5] A. Nofiyanto et al., "Studi Proses Pirolisis Beharbahan Jerami Padi terhadap hasil Produksi Char dan Tar Sebagai Bahan Bakar Alternatif," Proton, vol. 11, no. 1, pp. 21-28, 2019.

[6] Y. Bow, Rusdianasari, and L. Sutini Pujiastuti, "Pyrolysis of Polypropylene Plastic Waste into Liquid Fuel," in IOP Conference Series: Earth and Environmental Science, Nov. 2019, vol. 347, no. 1, doi: 10.1088/1755-1315/347/1/012128.

[7] RAN Moulita, R Rusdianasari, L Kalsum, "Biodiesel production from Waste Cooking Oil using Induction Heating Technology," Indonesia Journal of Fundamental and Applied Chemistry (IJFAC) 5(1), 2020.

[8] ES Yusmartini and Rusdianasari, "Separation process Biodiesel from Waste Cooking Oil using Ultrafiltration Membranes," Proceeding Forum in Research, Science, and Technology (FIRST), 2016.

[9] Yunsari, A Husaini, R Rusdianasari, "Effect of variation of Catalyst Concentration in the producing of biodiesel from Crude Palm Oil using Induction Heater," Asian Journal of Applied research for Community Development and Empowerment (AJARCDE) Vol. 3 No. 1, 2019.

[10] B. Nugroho Jati dan Rahyani Ermawati Balai Besar Kimia dan Kemasan, K. R. Perindustrian Jl Balai Kimia No, and P. Rebo, "Aplikasi katalis dalam mengkonversi limbah plastik menjadi energi (the application of catalyst for converting plastic waste as an energy source)."

[11] Rusdianasari, Y Bow, RAN Moulita, "Temperature Effect on the Biodiesel Quality from Waste Cooking Oil by Induction Heating," Journal of Physics: Conf. Series 1450 012003, 2020.

[12] S Susumu, R Rusdianasari, S Yusi, "Biodiesel Production from Waste Cooking Oil using Electrostatic Method," Indonesia Journal of Fundamental and Applied Chemistry (IJFAC) 3(3), 2018.

[13] R. Pratiwi and W. Dahani, "Pengaruh penggunaan katalis zeolit alam dalam pirolisis limbah plastik jenis hdpe menjadi bahan bakar cair setara bensin." [Online]. Available: www.kemenperin.go.id.

[14] Rusdianasari, A Syarif, M Yerizam, MS Yusi, L Kalsum, Y Bow, "Effect of Catalyst on the Quality of Biodiesel from Waste Cooking oil by Induction Heating," Journal of Physics: Conf. Series 1500 $012052,2020$.

[15] S Yunsari, Rusdianasari, A Husaini, "CPO Based Biodiesel Production using Microwaves Assisted Method" Journal of Physics: Conf. Series 1167(1) 012036, 2019.

[16] A. Saxena, H. Sharma, and G. Rathi, "Conversion of Waste Plastic to Fuel: Pyrolysis-An Efficient Method: A Review Design and Fabrication of motorized automated Object lifting jack View project Jaipur Tempo Traveller View project Conversion of Waste Plastic to Fuel: Pyrolysis-An Efficient Met," 2017. [Online]. Available: https://www.researchgate.net/publication/3133494 50.

[17] E Anzar, S Yusi, Y Bow, "Purification of Crude Glycerol for Biodiesel By-product by Adsorption using Bentonite," Indonesia Journal of Fundamental and Applied Chemistry (IJFAC) 3(3), 2018.

[18] JU Putra, L Kalsum, Y Bow, "Effect of DC Voltage on Prototype of Biodiesel Electrostatic Separator with Glyserin from Waste Cooking Oil," Indonesia Journal of Fundamental and Applied Chemistry (IJFAC) 3(3), 2018. 
[19] R Ploetz, R Rusdianasari, and E Eviliana, "Renewable Energy: Advantages and Disadvantages," Proceeding Forum in Research, Science, and Technology (FIRST), 2016.

[20] W. Trisunaryanti, "Optimation of time and catalyst/feed ratio in catalytic cracking of waste plastics fraction to gasoline fraction using cr/natural zeolite catalyst," Indones. J. Chem., vol. 2, no. 1, pp. 30-40, 2010, doi: 10.22146/ijc.21930.

[21] J. Ris, "Vol. 5, No. 2, Maret 2012 J. Ris. Kim.," vol. 5, no. 2, 2012.
[22] A. P. Ramadhan dan Munawar Ali, A. P. Ramadhan dan Munawar Ali Progdi Teknik Lingkungan, F. Teknik Sipil dan Perencanaan Universitas Pembangunan Nasional, and J. Timur, "Pengolahan Sampah Plastik Menjadi Minyak (Pengolahan sampah plastik menjadi minyak menggunakan proses pirolisis."

[23] Rusdianasari, Y Bow, RAN Moulita, Temperature effect on the biodiesel quality from waste cooking oil by induction heating," Journal of Physic: Conference Series 1450, 012003, 2020 